\title{
POTENSI EKOWISATA DAN KESEJAHTERAAN MASYARAKAT
}

\author{
Nencyana Natalia Herman ${ }^{1)}$ \\ Bambang Supriadi2) \\ Program Diploma Kepariwisataan Universitas Merdeka Malang \\ Jl. Bandung No. 1 Malang
}

Korespodensi dengan Penulis:

Nencyana Natalia Herman: Telp: 082338163302

Email: nencyana28@gmail.com

\begin{abstract}
East Ile Ape has potential tourism site which is suitable to be developed. It covers mangrove forest, sea, volcano as well as kampung adat Lamariang which never been touched by any other parties. By development of tourism site, it can help East Ile Ape to enhance its people welfare. It can be done by developing a commercial ecotourism site. Ecotourism is the one of tourism activities which concerns on natural conservation. This study was conducted by using descriptive quantitative analysis technique and linear regression which were processed by SPSS. The total number of samples is 40 . The result showed that the development of ecotourism is significantly correlated to local people welfare.

Keywords: Ecotourism; People Welfare; East Ile Ape district.
\end{abstract}

Pertumbuhan sektor pariwisata yang pesat maka usaha ekonomi mengalami pertumbuhan yang sama sesuai dengan peningkatan pendapatan daerah seperti pendapatan PDRB (Product Domestic Regional bruto), akan tetapi perumbuhan tersebut tida seirama yang dirasakan oleh masyarakat di kecamatan Ile Ape Timur, pertumbuhan pariwisata di daerah tersebut masih belum banyak berdampak pada peningkatan ekonomi secara lokal, sehingga dibutuhkan pemanfaatan potensi wisata alam di daerah ini untuk meningkatkan kesejahteraan masyarakat.

Konsep yang memanfaatkan potensi wisata kecenderungan pasar dalam bentuk back to nature ini merupakan usaha pelestarian keanekaragaman hayati dengan menciptakan kerja sama yang erat antara masyarakat yang tinggal disekitar kawasan yang perlu dilindungi dengan industri pariwisata. Ekowisata yang merupakan gabungan antara konservasi dan pariwisata dimana pendapatan yang diperoleh 
dari pariwisata seharusnya dikembalikan kepada kawasan yang perlu dilindungi untuk perlindungan dan pelestarian keanekaragaman hayati serta perbaikan sosial ekonomi masyarakat disekitarnya.

Rumusan Ekowisata pertama kali dikemukan oleh dikemukakan oleh Hector Ceballos-Lascurain pada tahun 1987 yaitu sebagai berikut: "Nature or ecotourism can be defined as tourism that consist in travelling to relatively undisturbed or uncontaminated natural areas with the specific objectives of studying, admiring, and enjoying the scenery and its wild plantas and animals, as well as any existing cultural manifestations (both past and present) found in the areas." "Wisata alam atau pariwisata ekologis adalah perjalanan ketempat-tempat alami yang relatif masih belum terganggu atau terkontaminasi (tercemari) dengan tujuan untuk mempelajari, mengagumi dan menikmati pemandangan, tumbuh-tumbuhan dan satwa liar, serta bentuk-bentuk manifestasi budaya masyarakat yang ada, baik dari masa lampau maupun masa kini."

Kemudian pada awal tahun 1990 disempurnakan oleh The International
Ecotourism Society (TIES) yaitu sebagai berikut: "Ecotourism is responsible travel to natural areas which conserved the environment and improves the welfare of local people". "Ekowisata adalah perjalanan yang bertanggung jawab ketempat-tempat yang alami dengan menjaga kelestarian lingkungan dan meningkatkan kesejahteraan penduduk setempat". Dalam pengembangan suatu daya tarik wisata menjadi kawasan ekowisata diperlukan potensi wisata yang asli, fasilitas yang memadai, aksesibilitas yang mudah dijangkau serta lingkungan yang bersih dan aman bagi para wisatawan yang berkunjung ke kawasan ekowisata.

Menurut BKKBN 1992, diacu oleh Nuryani 2007. Kesejahteraan merupakan suatu hal yang bersifat subjektif sehingga setiap keluarga atau individu di dalamnya yang memiliki pedoman, tujuan, dan cara hidup yang berbeda akan memberikan nilai yang berbeda tentang faktor-faktor yang menentukan kesejahteraan. Kesejahteraaan dibagi kedalam beberapa tingkatan yakni: keluarga pra sejahtera, Sejahtera 1, Sejahtera 2, Sejahtera 3 dan sejahtera $3+$. 
Tujuan artikel ini adalah untuk mengetahui pengaruh pengembangan kawasan ekowisata dalam meningkatkan kesejahteraan masyarakat di kecamatan Ile Ape Timur, maka penelitian ini mendeskripsikan pengembangan kawasan ekowisata gunung kecamatan Ile Ape Timur melakukan analisis pengaruh pengembangan kawasan ekowisata terhadap kesejahteraan masyarakat di kecamatan Ile Ape Timur.

\section{Metode Penelitian}

Lokasi penelitian secara geografis kecamatan Ile Ape Timur terletak di Kabupaten Lembata, dengan luas wilayah kecamatan $38.26 \mathrm{~km}^{2}$ (3,02\% dari luas keseluruhan Kabupaten Lembata). Batas wilayah Kecamatan Ile Ape Timur adalah Utara: Laut Flores; Selatan: Teluk Hadakewa; Timur: Tanjung Baja; Barat: Kecamatan Ile Ape.

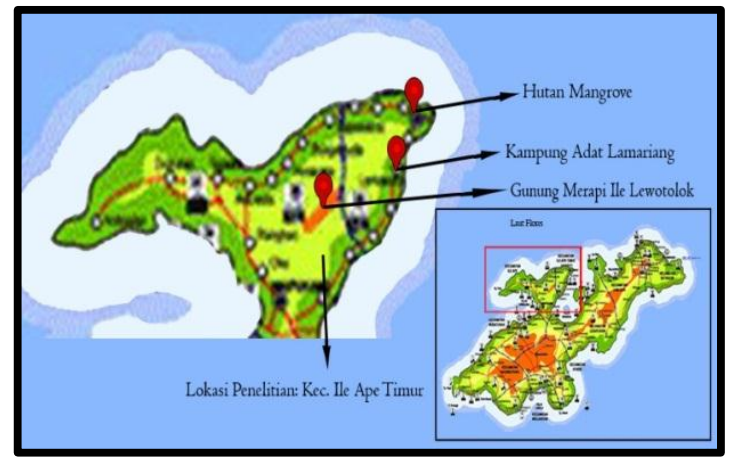

Gambar 1. Lokasi Penelitian

Populasi dalam penelitian ini adalah masyarakat prasejahtera kecamatan Ile Ape Timur dengan karakteristik pekerjaan sebagai petani dan nelayan sebanyak 45 responden. Jumlah sampel yang diambil sebanyak 40 responden.Ukuran sampel yang dibutuhkan ditetapkan dengan menggunakan formula yang dikembangkan oleh Slovin (1990).

Teknik pengumpulan data yang dilakukan:

a) Teknik Observasi: Pengumpulan data dilakukan dengan datang dan mengamati langsung ke lapangan. 
b) Quesioner

(Angket):

heteroskedastisitas. Regresi Linear

Pengumpulan data dengan

Sederhana dalam penelitian ini

memberikan daftar pertanyaan

dinyatakan dengan persamaan:

kepada responden untuk diisi.

c) Kepustakaan:

Teknik

$$
Y=\alpha+\beta X
$$

pengumpulan data dengan

cara mempelajari dari buku-

buku, tulisan ilmiah lainnya

Keterangan:

yang dipakai sebagai

$\mathrm{Y}=$ Kesejahteraan Masyarakat

$X=$ Pengembangan Kawasan Ekowisata

$\alpha=$ intersep (nilai $Y$ apabila $X=0$ )

pendukung kelancaran

penelitian.

Metode Analisis Data $\beta=$ slope (kemiringan garis regresi/ koefisien regresi)

menggunakan penelitian deskriptif kuantitatif. Sebelum pengolahan data dalam uji regresi linear sederhana, terlebih dahulu perlu dipastikan bahwa data tersebut lolos dalam syarat kelayakan dengan cara melakukan uji asumsi klasik yakni dengan uji HASIL DAN PEMBAHASAN

Hasil

\section{Uji Asumsi Klasik}

a. Uji Normalitas

Uji normalitas dilakukan dengan analisis grafik yaitu pada Normal P-P Regression Standardized Residual.

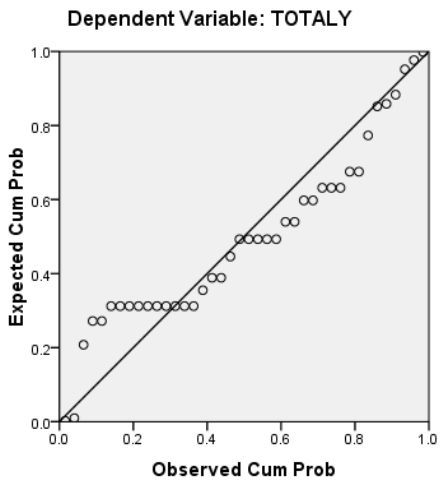

Gambar 2. Uji Normalitas dengan Histogram

Sumber: Hasil Pengolahan Data SPSS 2016 
Pada gambar 2 dapat dilihat bahwa titik-titik menyebar mengikuti data di sepanjang garis diagonal, hal ini berarti data berdistribusi normal.

\section{b. Uji Multikolinearitas}

Tabel 1. Uji Multikolinearitas

\begin{tabular}{|c|c|c|c|}
\hline \multirow{2}{*}{ No } & \multirow{2}{*}{ Variabel } & \multicolumn{2}{|c|}{ Collinearity Statistics } \\
\cline { 3 - 4 } & & Tolerance & VIF \\
\hline 1 & Pengembangan Ekowisata & 1.000 & 1.000 \\
\hline 2 & Kesejahteraan Masyarakat & 1.000 & 1.000 \\
\hline
\end{tabular}

Sumber : Hasil Pengolahan Data SPSS 2016

Nilai tolerance $>0,10$ maka tidak terjadi multikolinearitas. Jika, nilai tolerance $<0,10$ maka terjadi multikolinearitas. Nilai VIF $<10,00$ maka tidak terjadi multikolinearitas, jika nilai VIF > 10,00 maka terjadi multikolinearitas.

Maka nilai tolerance variabel pengembangan ekowisata dan kesejahteraan masyarakat yakni $1,000>0,10$. Sementara nilai VIF variabel

pengembangan ekowisata dan kesejahteraan masyarakat yakni 1,000 <10,00.

\section{c. Uji Heteroskedastisitas}

Bentuk pengujian heteroskedastisitas berupa gambar yang menunjukkan titiktitik yang dapat membentuk sebuah pola ataupun tidak membentuk sebuah pola.

Scatterplot

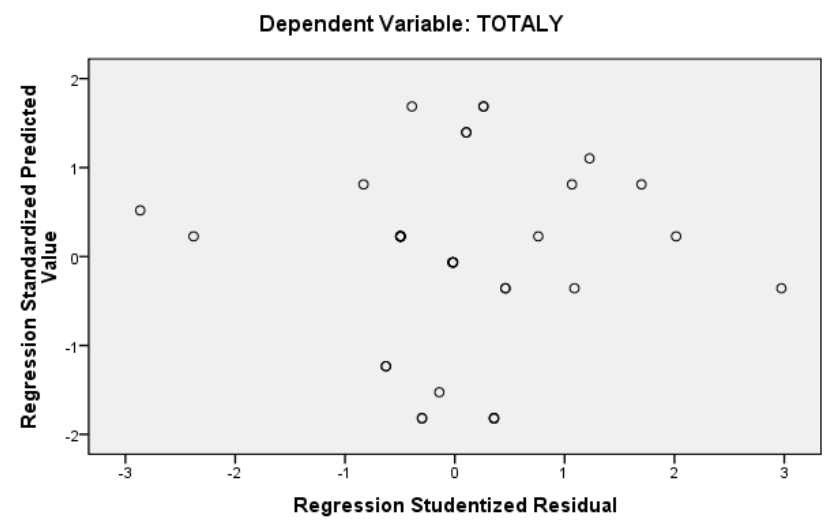

Gambar 3. Grafik Uji Heteroskedastisitas

Sumber : Hasil Pengolahan Data SPSS 2016 


\section{Grafik Scatterplot}

menunjukkan bahwa titik-titik yang merupakan data pada penelitian ini tidak membentuk pola tertentu atau dapat dikatakan tidak memiliki pola yang jelas dan penyebaran dari titik-titik tersebut berada di atas atau di bawah angka nol (0) pada sumbu, sehingga dapat disimpulkan data tidak terjadi heteroskedastisitas.

\section{Regresi Linear}

Analisis regresi ini dilakukan untuk mengetahui adanya pengaruh, mengetahui hubungan positif atau negatif, serta mengetahui besarnya pengaruh antara variabel pengembangan ekowisata terhadap variabel kesejahteraan masyarakat.

Tabel 2. Model Summary

\begin{tabular}{|l|r|r|r|r|}
\hline Model & \multicolumn{1}{|c|}{$\mathrm{R}^{\mathrm{a}}$} & $\mathrm{R}$ Square & $\begin{array}{c}\text { Adjusted R } \\
\text { Square }\end{array}$ & $\begin{array}{c}\text { Std. Error of } \\
\text { the Estimate }\end{array}$ \\
\hline 1 & .853 & .728 & .721 & 1.61476 \\
\hline
\end{tabular}

a. Predictors: (Constant), $X$

b. Dependent Variable: $Y$

Sumber : Hasil Pengolahan Data SPSS 2016

Nilai R (koefisien korelasi) sebesar 0,853 yang artinya nilai korelasi ini mengindikasikan bahwa hubungan antara variabel independen dengan variabel dependen termasuk dalam kategori sangat erat/kuat karena berada pada interval koefisien $\quad 0,85-0,99 \quad$ serta menunjukan bahwa hubungan antara variabel independen dan variabel dependen bersifat positif. 


\section{Uji Hipotesis}

a. Uji Serempak (Uji-F)

Tabel 3. Uji Serempak (Uji-F)

ANOVA $^{b}$

\begin{tabular}{|r|r|r|r|r|r|}
\hline \multicolumn{1}{|c|}{ Model } & \multicolumn{1}{|c|}{$\begin{array}{c}\text { Sum of } \\
\text { Squares }\end{array}$} & \multicolumn{1}{c|}{ df } & \multicolumn{1}{c|}{$\begin{array}{c}\text { Sean } \\
\text { Square }\end{array}$} & \multicolumn{1}{c|}{ F } & Sig. \\
\hline $1 \quad$ Regression & 265.317 & 1 & 265.317 & 101.754 & $.000 \mathrm{a}$ \\
Residual & 99.083 & 38 & 2.607 & & \\
Total & 364.400 & 39 & & & \\
\hline
\end{tabular}

a. Predictors: (Constant), $\mathrm{X}$

b. Dependent Variable: $Y$

Sumber : Hasil Pengolahan Data SPSS 2016

Analisis data untuk uji $\mathrm{F}$ pada tabel di atas nilai $\mathrm{F}$ hitung sebesar 101,754 sedangkan nilai $\mathrm{F}$ tabel $(\mathrm{a}=0,05 ; \mathrm{df}$ regresi $=$ $1 ; \mathrm{df}$ residual $=38$ ) adalah sebesar 2,46, karena F hitung > F tabel yaitu 101,754 > 2,46 serta memiliki nilai signifikan sebesar 0,000<a =0,05. Maka dapat disimpulkan bahwa variabel independen (pengembangan ekowisata) berpengaruh signifikan terhadap variabel dependen (kesejahteraan masyarakat).

b. Uji Parsial (Uji-T)

Tabel 4. Uji Parsial (Uji-T)

Coefficientsa

\begin{tabular}{|c|c|c|c|c|c|}
\hline \multirow[b]{2}{*}{ Model } & \multicolumn{2}{|c|}{$\begin{array}{l}\text { Unstandardized } \\
\text { Coefficients }\end{array}$} & \multirow{2}{*}{$\begin{array}{c}\text { Standardized } \\
\text { Coefficients }\end{array}$} & \multirow[b]{2}{*}{$t$} & \multirow[b]{2}{*}{ Sig. } \\
\hline & B & Std. Error & & & \\
\hline 1 (Constant) & 1.741 & 1.848 & & .942 & .352 \\
\hline TOTALX & .762 & .076 & .853 & 10.087 & .000 \\
\hline
\end{tabular}

a. Dependent Variable: $Y$

Sumber : Hasil Pengolahan Data SPSS 2016 
Hasil data dari tabel koefisien dalam analisis regresi adalah pada kolom B pada constant adalah 1,741, sedangkan nilai $X$ adalah 0,762, sehingga persamaan regresinya dapat ditulis sebagai berikut:

$$
Y=1,741+0,762 X
$$

Interprestasi dari regresi di atas adalah sebagai berikut:

a) Nilai variabel kesejahteraan masyarakat (Y) akan tetap / konstan sebesar 1,741 apabila nilai pengembangan ekowisata (X) tidak meningkat satu satuan.

b) Apabila nilai pengembangan ekowisata $(X)$ mengalami peningkatan satu satuan maka nilai variabel kesejahteraan masyarakat (Y) akan mengalami peningkatan sebesar 0,762 .

Berdasarkan interprestasi di atas maka dapat disimpulkan bahwa pengembangan ekowisata secara signifikan berpengaruh positif terhadap kesejahteraan masyarakat, sehingga apabila nilai dari pengembangan ekowisata meningkat akan diikuti dengan peningkatan nilai kesejahteraan masyarakat.
Pembahasan

\section{Deskripsi Kawasan Ekowisata dan Kesejahteraan Masyarakat}

Berdasarkan analisis diketahui bahwa responden cenderung setuju dengan adanya fasilitas yang memadai dikawasan ekowisata, misalnya dengan disediakan pusat informasi, pos penjagaan, rest area, dan toilet umum, akomodasi dai wialayah dekat wisata yang harus bernuansa adat lokal dan mempertimbangkan konsep ramah lingkungan seperti hasil penelitian yang daisampaikan oleh Supriadi (2016).

Berikut responden setuju dengan adanya potensi wisata di sekitar kecamatan Ile Ape Timur memiliki keindahan alam yang asli dan menjadi kawasan konservasi yang dapat diterima oleh masyarakat setempat serta lingkungan yang bersih dan aman. Terutama dengan adanya partisipasi masyarakat dalam menjaga kebersihan seperti menyiapkan tempat sampah di setiap bagian tertentu dan menjaga keamanan tempat ekowisata misalnya dengan menyiapkan beberapa orang yang berpenglaman dan mampu bersosial menjadi pendamping atau guide lokal untuk 
mendampingi wisatawan ketika melakukan pendakian ke gunung merapi Ile Lewotolok sehingga wisatawan dapat merasa aman dan responden yang setuju dengan adanya ketersediaan aksesibilitas atau alat transportasi yang menuju ke lokasi wisata. Misalnya, disediakan angkutan umum yang khusus dapat menjangkau kecamatan Ile Ape Timur.

Berikut masyarakat cenderung setuju dengan adanya peningkatan peluang kerja serta meningkatnya penghasilan. Seperti masyarakat dapat bekerja menjadi penjaga ataupun guide lokal dan mendapat penghasilan yang tetap. Responden cenderung setuju dengan kemudahan masyarakat dalam menyekolahkan anggota keluarganya serta dapat bersosialisasi dengan baik. Responden juga setuju dengan adanya sarana dan prasarana kesehatan yang memadai sehingga masyarakat tidak perlu mengeluarkan biaya yang banyak hanya untuk melakukan perawatan ataupun berobat ke luar kota.

\section{Pengaruh Kawasan Ekowisata Terhadap Kesejahteraan \\ Masyarakat}

Pengembangan ekowisata mempunyai pengaruh terhadap kesejahteraan masyarakat kecamatan Ile Ape Timur. Potensi wisata hutan mangrove, gunung merapi ile lewotolok, dan kampung adat lamariang yang asli serta dapat diterima oleh masyarakat setempat dapat mempengaruhi peningkatan pendapatan masyarakat kecamatan Ile Ape Timur. Misalnya, dengan adanya suatu daya tarik wisata seperti rumah adat Lamariang dapat memberikan peluang kerja bagi masyarakat, masyarakat dapat berjualan souvenir atau kuliner khas daerah. Fasilitas serta aksesibilitas yang tersedia dan memadai dapat menarik wisatawan yang akan berkunjung sehingga semakin meningkatnya jumlah wisatawan yang berkunjung maka semakin tinggi penghasilan yang didapatkan oleh masyarakat setempat . Sedangkan, lingkungan ekowisata yang bersih dan terawat serta aman menjadi salah satu pengaruh untuk menarik wisatawan yang berkunjung agar wisatawan dapat 
merasa nyaman dan aman. Sehingga, ketika wisatawan domestik maupun mancanegara yang berkunjung ke tempat ekowisata mendapat kesan yang tidak terlupakan.

Dengan adanya pengembangan suatu kawasan ekowisata dapat memberikan lapangan pekerjaan bagi masyarakat lokal, sehingga dapat menunjang dalam peningkatan kesejahteraan masyarakat baik dari segi pendapatan, pendidikan maupun kesehatan. Perlunya perhatian khusus dari pemerintah setempat untuk memberikan pelatihan dan sosialisasi kepada masyarakat serta memperkenalkan kawasan ekowisata tersebut melalui massa, media sosial dan promosi yang dapat menarik perhatian wisatawan sehingga dapat meningkatkan kesejahteraan masyarakat kecamatan Ile Ape Timur.

\section{KESIMPULAN}

Berdasarkan hasil penelitian dapat ditarik kesimpulan: Pengembangan kawasan ekowisata hutan mangrove, gunung merapi ile lewotolok, dan kampung adat lamariang yang didukung dengan fasilitas yang memadai, dengan adanya pusat informasi, pos penjagaan, rest area, dan toilet serta daya tarik wisata yang asli, aksesibilitas atau alat trasportasi menuju ke kawasan ekowisata yang tersedia setiap saat dan lingkungan yang bersih dan aman bagi wisatawan dapat menunjang kelancaran dalam pengembangan kawasan ekowisata.

Kesejahteraan masyarakat diketahui dengan adanya peluang kerja serta peningkatan pendapatan melalui pengembagan potensi ekowisata seperti hasil penelitian Supriadi (2016) , masyarakat juga dapat lebih mudah dalam menyekolahkan anggota keluarga serta dapat bersosialisasi secara baik dengan sesama dan adanya sarana dan prasarana kesehatan yang memadai, karena adanya pengembangan kawasan ekowisata di kecamatan Ile Ape Timur. Potensi wisata yang asli dan kawasan konservasi yang dapat diterima masyarakat serta lingkungan yang bersih dan aman memiliki rating tertinggi lalu dengan adanya fasilitas yang memadai serta aksesibilitas yang mudah dapat mempengaruhi peningkatan kesejahteraan masyarakat 
mulai dari pendapatan, pendidikan dan kesehatan.

Pengembangan ekowisata mempunyai pengaruh terhadap kesejahteraan masyarakat kecamatan Ile Ape Timur, yakni dengan adanya pengembangan suatu kawasan ekowisata dapat memberikan lapangan pekerjaan bagi masyarakat lokal, karena dapat menunjang dalam peningkatan kesejahteraan masyarakat baik dari segi pendapatan, pendidikan maupun kesehatan, seperti membuka kesempatan kerja di bidang pemandu wisata seperti hasil penelitian Nanny (2016).

Rekomendasi berdasarkan kesimpulan yang telah diambil, dapat dikemukakan beberapa saran yang diharapkan dapat memberikan manfaat bagi masyarakat maupun pihak lain. Beberapa saran atau masukan yang dapat diberikan antara lain: Bagi Pemerintah dan Pengelola yaitu Disarankan kepada pemerintah setempat agar memaksimalkan motivasi untuk peningkatan kesejahteraan. Sebaiknya pemerintah melakukan pengembangan potensi wisata menjadi kawasan ekowisata karena dapat menjadi program jangka panjang tanpa merusak potensi wisata yang ada dan pemerintah seharusnya melakukan pendataan yang lebih akurat mengenai informasi lokasi wisata kecamatan Ile Ape Timur serta data-data akomodasi dan tingkat wisatawan domestik maupun nusantara yang berkunjung.

Bagi Masyarakat yaitu Masyarakat setempat dapat menjadikan hasil penelitian ini sebagai pedoman dan perlu berpartisipasi langsung dalam pengembangan kawasan ekowisata di kecamatan Ile Ape Timur. Misalnya: Masyarakat lokal menyediakan akomodasi yang layak dan dapat dijadikan tempat penginapan bagi wisatawan yang berkunjung, masyarakat dapat berjualan souvenir atau makanan khas daerah, masyarakat juga bisa dilibatkan untuk menjaga keamanan kawasan ekowisata sehingga wisatawan merasa aman ketika berwisata sehingga dapat meningkatkan pendapatan.

\section{DAFTAR RUJUKAN}

Algifari. 1997. Analisis Regresi Teori, Kasus dan Solusi. Yogyakarta.

Badan Pusat Statistik, 2016. Kabupaten Lembata dalam Angka 2016. 
Badan Pusat Statistik, 2016. Statistik Kecamatan Ile Ape Timur 2016.

Fandeli, Ch, 2000. Pengembangan Ekowisata dengan Paradigma dalam Pengusahaan Ekowisata, UGM Yogyakarta.

Flamin Alamsyah, dkk, 2013. Potensi Ekowisata dan strategi pengembangan Tahura Nipa-Nipa kota Kendari. Sulawesi Tenggara.

Hadinoto Kusudianto, 1996. Perencanaan Pengembangan kawasan pariwisata. UI Press Jakarta.

Hanny Aryunda, 2011. Jurnal Dampak Ekonomi Pengembangan Kawasan Ekowisata Kepulauan Seribu.

Kusmayadi, dkk. 2000. Metodologi Penelitian dalam Bidang Kepariwisataan. Pt. Gramedia Pustaka Utama Jakarta.

Ndakulara Erwin, dkk, 2013. Jurnal Analisis Faktor-Faktor Yang Mempengaruhi Kesejahteraan Masyarakat Kabupaten/Kota Di Provinsi Bali.

Permanasari I. Kusuma, 2011. Jurnal Pemberdayaan Masyarakat melalui Desa Wisata Dalam Usaha Peningkatan Kesejahteraan.

Prastyaningrum Wahyu, 2009. Jurnal Analisis Faktor yang Mempengaruhi Kesejahteraan Masyarakat.

Pulungan M. Soleh, 2013. Optimalisasi Pengembangan Potensi Ekowisata Sebagai Objek Wisata Andalan di
Kabupaten Kutai Kartanegara Provinsi Kalimantan Timur.

Riduwan, 2008. Dasar-dasar Statistika Alfabeta, Bandung.

Sugiharto Ugi, 2007. Tingkat Kesejahteraan Masyarakat Nelayan Desa Benua Baru Ilir Berdasarkan Indikator Badan Pusat Statistik.

Sugiyono, 2006. Metode Penelitian Kuantitatif, Kualitatif dan $R \mathcal{E} D$, edisi Ke - 2, CV. Alfabeta, Bandung.

Supriadi, B. 2016, 'Pengembangan Ekowisata Pantai Sebagai Diversifikasi Mata Pencaharian', Jurnal Pariwisata Pesona, 1(1), p. 20. Available at: http:/ /jurnal.unmer.ac.id/index .php/jpp/article/view/369.

Supriadi, B. and Roedjinandari, N., 2016, 'Investigasi Green Hotel Sebagai Alternatif Produk Ramah Lingkungan', Green Technology Innovation, International Conference, pp. 19.

Supriadi, B. and Roedjinanndari, N., 2016, 'Kompetensi pendampingan pemandu wisata lokal sebagai developers of people', Jurnal Pariwisata Pesona, 2(1), pp. 72-86. 